\title{
The Form, Function, and Value of Buginese Utterances of Bone Society
}

\author{
Andi Tenri Sua \\ Universitas Negeri Makassar, Jln. Bonto Langkasa, Kampus Gunung Sari, Makassar, Sulawesi Selatan, Indonesia \\ Anshari \\ Universitas Negeri Makassar, Jln. Bonto Langkasa, Kampus Gunung Sari, Makassar, Sulawesi Selatan, Indonesia \\ Mayong Maman \\ Universitas Negeri Makassar, Jln. Bonto Langkasa, Kampus Gunung Sari, Makassar, Sulawesi Selatan, Indonesia
}

\begin{abstract}
This study discusses the exploration of form, function, and value of Buginese utterance of Bone society. This study aims at discovering, exploring, and explaining the form, function, and value Buginese utterance of Bone society. This study theoretically could be used by scientists to utilize the results of this research as new insights and materials for further studies of oral literature of Buginese society in Bone. The results showed that the utterance of Buginese society in Bone has six forms namely, proverbs, parables, sayings, metaphor, irony, and idioms. The Buginese utterance of Bone society has four functions, namely educative function, the personal ethics function, moral function, and social function. It has three values, namely religious, philosophical, ethical values. Religious value contains the value of the recognition of God and recognition of the good destiny and fate. Philosophical value contains the value of man as a creature of God, man as a personal being, and human beings as social creatures. Ethical value contains the value of ethics against God, against oneself ethics, and ethics of fellow human beings.
\end{abstract}

Index Terms - form, function, and value for the public expression of Bugis Bone

\section{INTRODUCTION}

Culture is very closely linked to the public. Herskovits and Malinowski (in Bidney, 1996, p. 276) explain that everything contained in the society is determined by the culture which is owned by the community itself. Culture has a hereditary nature from generation to generation. It contains the entire understanding of values, norms, science and all the social and religious structure. Culture is a complex whole which contains knowledge, belief, art, morals, law, customs, and other abilities from any person as a member of society that has a way of life upheld by members of the public to form a local wisdom.

According to Geertz (1993), local knowledge is a form of culture that reflects the way of life of local communities, in substance, it is the values and norms prevailing in a society that is believed to be true and becomes a reference in the act and behavior every day. In other words, local wisdom is the ability to empower and address the noble values of the local culture. Therefore, local knowledge is a central entity for human dignity in the community.

Civilized society has always had language as a prerequisite to survive, and development of society and culture because language strengthens social and cultural development (Nababan, 1984, p. 52). The language used by a speech community will reflect the attitudes, perspectives, and beliefs held by its speakers. Moreover, the words used also always refer to objects, events, and anything that are symbolic and metaphoric.

Furthermore, Octavian (2006) explains that the form and meaning owned by a community culture will form a world view. The view of the world is like a big picture of how people view the existence of the world, and the actions are taken to events and interpret all the events. Society and culture also have a set of values to do something. View of the world is the understanding of life. The formation of worldview tends to be influenced by the religious community.

In addition, Liliweri (2003, p. 12) states that the worldview is a perspective of a speech community and a belief system that are formed under the influence of cultural values possessed. One of the speech communities in South Sulawesi is the Buginese community in Bone. Buginese community in Bone has much potential local wisdom used as signposts or guidance in their living. These signs serve as a guide, a reflection of nature, and personality of Buginese community in Bone. Those values are in the form of ethics, manners in the house, polite in public, including issuing opinions, talk to parents, dress, eating, and treating others.

Buginese language in Bone is a product of society reflecting the local culture Bone. People in Bone in everyday life always interact with their environment using a custom system that takes place continuously and bound by a sense of shared identity in social unity. The characteristics of community among fellow Bone in being always humble, gentle, polite toward each other are reflected in the utterances used by people in Bone. 
Buginese language is the language applied by the community in Bone to communicate. As a language which unifies inter-ethnic, Buginese language is mastered by all members of the community owners, and it serves as a communication tool to understand the culture (Anwar, p. 2007). Buginese language has an utterance that reflects the local culture of Bone. The utterance has a function as a symbol of cultural identity of Bone which is considered synonymous with nature and behavior Bone. The utterance is one of the styles that is in the form of figurative language in the form of a sentence or group of words that are dense, compact, simple, and contains the norms, values, advice, comparisons, parables, principles and behavior. The use of the Buginese utterance by the Bone community is believed to have a range of values which is included in the national cultural values which are the local genius.

Correspondingly, Suseno (1991, p. 87) explains that the utterances in various forms and types of Buginese language describe the behavior of individuals and the way of life in Bone. The use of these utterances are typically used to quip, advice, affirm and make cautious. The utterances in Bone implies a public mindset that contains the value of life in the form of firmness, rigidity, simplicity, cooperativeness, respect for elders, applying thoughtful, thinking before acting, and compliance.

Today in Bone, the case of silting moral values has occurred and it is accompanied by the identity and personality crisis, especially the younger generations. Therefore, it can threaten the resilience of local and national culture. The local wisdom of Buginese in Bone is an embellishment of culture which becomes extinct. Therefore, some steps need to be implemented in an attempt to maintain the existence of local and national culture in Bone. Cultural behaviors such as refinement, sense of fairness and balance between the rights and obligations become the essence of local cultural values that must be maintained in Bone. Those things are crystallized in the language. It means that the language serves as a transmitter of cultural values. In fact, if someone wants to explore a culture system, then he or she should be included in the system to learn the language first. Therefore, the study of form, function, and value of Buginese utterance in Bone is interesting to be conducted.

\section{LITERATURE REVIEW}

\section{A. Definition of Utterance}

Poerwadaminta (1976, p. 1129) states that utterance is a word or group of words specifically to express an intention figuratively. Soedjito (1990, p. 220) defines the utterance as a compound word (phrase) whose meaning has been fused and should not be construed with the meaning of the elements that make it up, for example, aligned with, talking about, thank you, and based on. In these instances, it shows that the words (to, with, and on) are fixed utterance that cannot be changed or replaced by the other words. In this sense, it seems that Poerwadarminta and Soedjito equalize the phrases and idioms.

In Indonesian Dictionary (2005, p. 417) idiom is a construction whose meaning is not the same as the combined meaning of its element. For example kambing hitam (scapegoat) in the Indonesian sentence "dalam peristiwa itu hansip menjadi kambing hitam, padahal mereka tidak tahu apa-apa" (In the event, the security became a scapegoat, but he does not know anything). Keraf (2005, p. 109) also has a similar explanation that the idiom is structural patterns that deviate from the rules of the common language, usually a phrase, whereas meaning cannot be explained logically or grammatically by relying on the meaning of the words that form it, for example, makan tangan (eating hand) and makan garam (eating salt) in the form of Indonesian phrases. These examples are idiom because the means do not the same as the words that form it or cannot be explained grammatically. For examples of makan garam means having a lot of experience, makan tangan means exposed to punch or boxing.

Therefore, it can be concluded that the utterance is a word or words expressed as the wisdom of crowds derived from the experience of a long life.

\section{B. Forms of Expression}

The first is proverbs. In Indonesian Dictionary (2005, p. 858), there are two definitions of proverb. First, it is a group of words or sentences with fixed structure, usually an analogizing specific intention. Second, it is a solid brief phrase or sentence, unbiased comparisons, parables, advice, life principles or rules of behavior. Danandjaya (1991, p. 28) explains that proverbs are fixed sentence stating its point by parable, satire, comparisons or similes and proverbs are groups of words or sentences with fixed arrangement. According to Danandjaya (1991, p. 28), there are some characteristics of proverbs. It must be a single sentence, it is not enough that only one word, such as God, mad. It has a standardized form. It has the vitality or viability of oral tradition, which can be distinguished from other forms of writing poetic, advertising, news, and etc.

The second is sayings. It is a proverb that contains advice or teachings of the elders, usually uttered to break interlocutors (MONE, 2005, p. 825). Gaffar (Aliana, Zakaria, and Joseph, 1984:, p. 24) also has a similar explanation that sayings are a short sentence in figurative form that is used to break the conversation. For example adage, tong kosong nyaring bunyinya (Empty barrel has a loud sound). This sentence analogize someone who has a lot of talk but less action. Thus, the specific characteristic of maxim is breaking interlocutors.

The third is the byword. In the Big Indonesian Dictionary (2005, p. 847) it has two meanings, namely (1) ridicule, mockery, sarcasm of being bandied people; (2) funny word to satirize. According to Badudu (1984, p. 7) byword is the words that became popular which are always uttered repeatedly either containing encouragement or containing. For 
example, Indonesian words oleh rakyat dari rakyat untuk rakyat (by the people, of the people, and for the people) which are originally put forward by the New Order government then it is called a byword since it is often imitated by the people and uttered many times by people in different places. Therefore, it can be stated that special characteristics of byword is a form of speech that is short, concise, uttered many people many times.

The fourth is parable. It is an utterance about the condition or behavior of a person who uses the words of the parable or a comparison for example as and like (Badudu, 1984). It is also explained more clearly by Gaffar (Aliana, Zakaria, and Joseph, 1984: 28) that the parable is a sentence that likens or separates something like loveliness or favor someone or with the state of the natural surroundings, usually starting with the comparison words: like or as if.

The fifth is imagery. It is figuratively rhyming and rhythmic and sometimes like a poem, but in a shorter form, which is about only one lyric Gaffar (Aliana, Zakaria, and Joseph, 1984:, p. 33). Badudu (1984, p. 7) defines imagery like parable but it is accompanied by explaining sentence. For example, tua tua keladi in Indonesian means that someone is old, but he still behaves poorly.

The sixth is metaphor. It is also almost the same as the imagery and similes. The difference is that the imagery has massage and content, while metaphor only has massage, but it is figurative massage. For more detail, Gaffar (Aliana, Zakaria, and Joseph (1984, p. 35) define metaphor as a parable that uses natural reasonable comparison with the corresponding different nature itself in his life. Thus, a special feature of the metaphor is in the form of message in which the massage is figurative, and it refers to the properties of natural objects or natural as the real circumstances in life. For example, api makan seakan (fire eats as) analogizes grudging people to others. Another example is air di daun talas (the water is in taro leaves) means that someone has been given the teachings but he did not use them.

The seventh is idioms. Badudu (1984, p. 146) explains that the idiom comes from the Latin meaning word or group of words that typically have a figurative sense. In Indonesian Dictionary (2005, p. 417), it is explained more clearly that the idiom is a construction whose meaning is not the same as the combined meaning of its elements, such as kambing hitam (a scapegoat) in the sentence dalam peristiwa itu hansip menjadi kambing hitam, padahal mereka tidak tahu apaapa (in the event the security became scapegoat, but he did not know anything). Keraf (2005, p. 109) also has a similar explanation that the idiom is structural patterns that deviate from the rules of the common language, usually a phrase. However, the meaning cannot be explained logically or grammatically by relying on the meaning of the words that form it, for example, makan tangan (eat hand) and makan garam (eat salt). These examples are included the idiom because their meanings are not the same as the meaning of the words composing it. In addition, they cannot be explained grammatically.

\section{The Functions of Utterance}

A wide variety of functions contained within a traditional utterance can be classified into four types, namely educative function. According to Indonesian Dictionary (2005, p. 284) the meaning of educative is didactic instructive. Therefore, educative function is a function of educating. Danandjaya (1991, p. 32) explains that the traditional utterance has a function as an educational tool. In addition, Gaffar (Aliana, Zakaria, and Joseph (1984, p. 6) state that the educative function on a traditional utterance can be for children and adults. Educating function in the context of ethnic traditional subjects refers to education in schools and also refers to the character education in the environment around the family. It can be inside or outside the home.

The second function is personal ethics. Bertens $(2007$, p. 4) reveals that the word ethics comes from the Greek word which means habit. In Indonesian Dictionary (2005, p. 309) ethics is defined as the science of what is good and what is bad and about right and moral obligation. Thus, ethics is a set of principles or values related to morals or values of right and wrong embraced by a group or community. In terms of the object of study, ethics is divided into two kinds, namely the ethics of virtue and ethical obligations (Bertens, 2007, p. 212).

Ethics of virtue relates to the principles and moral rules to be human, while the ethical obligations relates the principles and moral rules to do something. Ethics of virtue tried to answer question that "what kind of person that I should be". Meanwhile, the ethics of obligation try to answer the question "what I have to do or what I should do". The function of personal conduct refers to the ethics of virtue so that every phrase that indicates how the human should be or how the human nature should be would be categorized as an utterance that has a function of personal conduct.

The third is moral function. Bertens (2007, p. 4) explains that the word of moral means the customs. Furthermore, Bertens (2007, p. 212) explains that in terms of the object of study, ethics is divided into two kinds, namely the ethics of virtue and ethical obligations. Virtue ethics refers to the principles and moral rules to be human, while the ethical obligation refers to the principles and moral rules to do something. In Indonesian Dictionary $(2005$, p. 754) moral is interpreted as a character, manners, or morality. Therefore, moral functions are the functions that relate to ethical obligations, the principles and moral rules to do something good or bad doctrine commonly accepted regarding the actions, attitudes, and obligations of a person.

The fourth is social function. Koentjaraningrat (1979) explains that the social function of the traditional utterances are the functions that refer to the relationships within the community. It is in line with the meaning of the word social in the Indonesian Dictionary (2005, p. 1084), which is regard to the community. Therefore, the social function referred to in this study is a function that involves human relationships in society.

D. The Value of Expression 
Iskandar (1989, p. 864) states that the value means the degree, quality, quality, extent, and nature elevation of thought, religion, society, and others. On the other hand, in Indonesian Dictionary (Depdiknas, 2005), the value is the properties which is important or useful to humanity. It means that the value is something valuable, important and necessary for human life. It is in line with the opinion of Sedyawati (2004) which states that the value is something to be treasured by man or group of men.

The Buginese utterance in Bone regency contains various values of life. Spradly (1980) stated that the concept of value appears to be one important topic in the study of literature. This is because the value that is attached to the speaker's utterance will differentiate one utterance with another utterance. Referring to some expert opinion on the value of a work of literature as well as in the form of utterance, more specifically the values which usually contain in the utterance are religious value, philosophical value, and ethical value.

\section{RESEARCH METHODS}

This research is an ethnographic research. Ethnographic was chosen based on the consideration that this study aims at describing the depth and holistic form, function, and value of Buginese utterance of Bone society naturally. There were three aspects of this study. The first is the form of Buginese utterance of Bone. The second is the function of Buginese utterance of Bone Society. The third is the value of the Buginese utterance of Bone society. In addition, this research was categorized into types of ethnographic research because the data were taken through a phenomenon observed in everyday life.

The data were collected by using several techniques, namely (1) observation, (2) interviews, and (3) study the documentation. Observation techniques were used to observe people's behavior in Bone to communicate each other. This observation techniques were followed by field notes. The recorded data are in the form of the situation of the use of utterance which includes background, participation, function, and expression of interest. In-depth interview techniques were implemented to informants to obtain the forms of Buginese utterance which includes proverbs, sayings, parables, metaphor, and byword. This interview techniques use instruments such as interview guides, and recording techniques. Documentation study was conducted by recording the data in the form of written utterance contained in the book entitled Kerajaan Bone di Lintasan Sejarah dan Ensiklopedia Kebudayaan Bone (Kingdom of Bone in track history and Culture Encyclopedia in Bone).

Data were analyzed using ethnographic analysis techniques (Spradly, 1980). Generally, the groove of ethnographic analysis is originated from the domain analysis, then it is followed by a taxonomic analysis, componential analysis, and analysis of the cultural theme.

Domain analysis was carried out by the principle of reading data of the utterance repeatedly and carefully in order to obtain the data that actually contains the form of Buginese utterance, the functions of Buginese utterance, and the values of Buginese utterance in Bone. This domain analysis is guided by the instrument guide for domain analysis. Domain analysis is used to find a number of general concepts (cover term) of the Buginese utterance.

Taxonomic analysis was conducted after the domain analysis. This analysis is looking for a number of concepts of citizens (include term) of any concept of public domain found during the domain analysis. From the domain analysis, the general concepts are found, for example, the dimension of utterance form, the dimensions of the utterance meaning, (3) the dimensions of the use of the utterance. The element of these aspects are then searched. The elements in this case are a smaller element (small portion) of the three domains. This step is guided by a guide instrument for taxonomic analysis.

Componential analysis was executed to analyze the smaller elements, and to analyze the internal structure of each of the elements that have been found. For example, on the findings of the style of narrative utterance, it is found that the style of narrative utterance of Buginese includes (1) proverb, sayings, parable, byword, and idiom: (2) the kind of language used; (3) the narrative as a motif motivation, innuendo; and (4) the narrative utterance in formal education activities.

Cultural theme analysis was undertaken to find three things, namely (1) the themes of each domain, (2) the relationship among the domains, and (3) the general theme of the entire doamin. In the phase of cultural theme analysis, three sets of data analysis instruments were used, which refer to the focus of the research problem. The instruments of data analysis refer to three aspects. The first is the form of Buginee utterance of Bone society. The second is the meaning of Buginee utterance of Bone society. The third is the function of Buginee utterance of Bone society.

\section{RESULTS AND ANALYSIS}

After going through the process of reduction, classification and analysis, it is found that Buginese utterance has six forms, including proverbs, parables, sayings, metaphor, byword, and idioms. Overall, the researchers found 14 forms of proverbs, 11 parables, 14 sayings, 12 metaphors, 11 bywords, and 12 idioms.

Buginese utterance in Bone present and serves four kinds of functions, which include educative function, personal ethics function, moral function, and social function. Each of these functions has a good message that is useful for Bone society to maintain the existence of their traditional values. Most of function of Buginese utterance in Bone innumerable is an educative function. The utterances contain messages about work ethic, consistent attitude, frugality, 
hygiene, patient and sincere, independent attitude, thanksgiving favors, changing bad habits, self-confidence, the pursuit of achievement, unyielding, and neutral.

Buginese utterance in Bone also contains the function of ethics which refers to the ethics of virtue. Therefore, any expression that shows how it should be human nature will be categorized as an expression that has a function of personal conduct. The function of personal ethics of Buginese utterance in Bone contains a message about the attitude of introspection, embarrassed, assertiveness, diligent, politeness, away from the rough nature, a realistic attitude, obeying the truth, loving parents, responsibilities, compliant, away from the nature of the griping, and away from greed.

The moral functions in Buginese utterance in Bone contain a message about honest, trustworthy, appreciate kindness, guard of honor, and resignation. Three different messages with a social function were found in the Buginese utterance in Bone that represents local wisdom that is about maintaining unity, caring for others, and friendly attitude.

After going through the process of reduction, classification and analysis, it is found that the Buginese utterance in Bone present and serves three kinds of values namely religious, philosophical, and ethical values. Religious value is the value associated with divinity or entanglement with God with all of its Creation. The value is a value that is often found in the utterance. Creed or belief is a most fundamental values and principles for humans. The faith will compensate for a person's character in which the character is the triumph of the desire of some human desire to live in a row. The results of this research showed that in fact the value of the Buginese utterance of Bone Society has religious values containing recognition of the existence of God and the recognition of their good destiny and fate. A philosophical value is the contemplation and thinking about the world and the life hereafter. With these philosophical values, people in Bone are not looking for human nature but recognizing human life as a fact of life that must be accepted, only to find the essence of man where it comes from and where to go later. Based on the research finding, it is found that the Buginese utterance of Bone society has a value of man as a creature of God, man as a personal being, and human beings as social creatures.

Ethical Values in Buginese utterance in Bone highly regulates the life which is based on religious values and customs of the local community. Ethical values in the Buginese utterance in Bone cover ethical society against its creator (God), ethical about themselves, and ethical towards their fellow human beings. The personal ethical concerns man's relationship with the life and her-self. Humans in developing their life must understand ethics to themselves such as being realistic, introspection, assertive, away from the abusive nature, neutral, consistent, honest, loving parents, responsible, friendly, trustworthy, not greedy, diligent, never give up, patient and sincere, independent, diligent, obedient to the truth, changing bad habits, hygiene, guard her honor, saving, work ethic, self-confidence, the pursuit of achievement, having a sense of shame, being polite and well mannered, obedient, and avoiding rough nature Ethics to the community which is a form of judgment by others in a person to interact with each other. The ethics can be preserving unity among each other and appreciating the kindness of others.

\section{Discussion AND CONCLUSION}

The Buginese utterance in Bone has six forms namely proverbs, parables, sayings, metaphor, byword, and idioms. Overall, it is found 73 utterances, covering 13 proverbs, 11 parables, 14 sayings, 12 metaphor, 11 bywords, and 12 idioms. It means that the Buginese utterance in the form of proverbs is 18\%, parables is 15\%, sayings are $19 \%$, metaphor is $16 \%$, byword is $15 \%$, and idiom is $16 \%$. Thus, the Buginese utterance in Bone is mostly in the form of sayings.

The Buginese utterance in Bone has four functions namely educative function, personal ethics function, moral function, and social function. There are 24 utterances which have educative function that contains a message about work ethic, consistent attitude, frugality, hygiene, patient and sincere, independent attitude, thanksgiving favors, change bad habits, self-confidence, the pursuit of achievement, unyielding, and neutral. In addition, there are 27 utterances which have the function of ethics personal which contain the message about the attitude of introspection, shame, assertiveness, perseverance, politeness, diligent (not lazy), away from the abusive nature, being realistic, obedient to the truth, loving parents, responsibility, submissive, away from the nature of the griping, and avoid greed. There are 13 utterances which have the moral function and contain a message about the nature of honesty, trust, appreciate kindness, honor guard, and resignation. Furthermore, there are 9 utterances which have a social function that contains a message about preserving the unity, caring for others, and friendly attitude.

The Buginese utterance in Bone has three kinds of value, including the religious, philosophical, and ethical values. There are two utterances that have religious value containing the value of recognition of God and the recognition of good destiny and fate. There are 8 utterances about philosophical value containing the value of man as a creature of God, man as a personal being, and human beings as social creatures. Meanwhile, there are 63 utterances containing ethical values consisting of the ethics of god, the ethics of self, and ethics of fellow human beings.

\section{REFERENCES}

[1] Aliana, Zainal Arifin; Sakaria, Ahmad Rozi; and Joseph, Hasfi. (1984). Oral Literature Ogan. Jakarta: Development and Language Development Center, Ministry of Education and Culture.

[2] Anwar, Idwar. (2007). Culture Encyclopedia Luwu. Makassar: Library Sawerigading.

[3] Badudu, JS (1984). Sari Indonesian Literature. Bandung: Pustaka Prima. 
[4] Bertens, K. (2007). Ethics. Jakarta: Gramedia Pustaka Utama.

[5] Bidney, David. (1996). Theoretical Anthopology. Second Edition. Nen Jersey: Transaction Publishers.

[6] Danandjaja, James. (1991). Indonesian folklore. Science Gossip, Legends, and Other. Jakarta: Pustaka Utama Grafiti.

[7] Geet, Cliffod. (1993). Tafsir kebudayaan. Terjemahan fransisco Budi Hardiman. Yogyakarta: Kanisius.

[8] Iskandar, Teuku. (1989). Kamus Dewan. Kuala Lumpur: Dewan Bahasa dan Pustaka.

[9] Indonesia Dictionary. (2005). Jakarta: Balai Pustaka.

[10] Keraf, Gorys. (2005). diction and style of language, Jakarta: Gramedia Pustaka Utama.

[11] Koentjaraningrat. (1979). Man and Culture in Indonesia. Jakarta: Djambatan.

[12] Liliweri, Alo. (2003). Meaning of Culture and Intercultural Communication. Yokyakarta: LKIS.

[13] Ministry of Education. (2005). Indonesian dictionary. Jakarta: Balai Pustaka.

[14] Nababan, PWJ. (1984). Sosiolingguistik. Jakarta: PT Gramedia.

[15] Octavian. (2006). Nilai Culture in Minangkabau expression: A Study of Perspective Antropologi .In linguistics journals Indonesian Linguistics 1: 115-129.

[16] Poerwadarmita, WJS. (1976). Indonesian General Dictionary. Jakarta: Balai Pustaka.

[17] Sedyawati, Edi (Eds). (2004). Malay Literature Regional Cross. Jakarta: Ministry of Education Language Center.

[18] Soedjito. (1990). Vocabulary Indonesian. Jakarta: PT Gramedia Pustaka Utama.

[19] Spradley, James P. (1980). Participant Observation. New York: Holt, Rinehart and Winston.

[20] Suseno and Franz Magnis. (1991). Ethics Falsafi Analysis of Java a Java Life Policy. Jakarta: PT. Gramedia Pustaka Utama.

Andi Tenri Sua, was born on June $22^{\text {th }} 1972$ at sub district Ponre. Now she lives at Jl. Gunung Rinjani No. 7 Watamone. She started her education in SD Inpres 3/77 Watampone on 1879. Then she continued to SMPN 4 Watampone on 1984, after graduated she joined SMAN 1 Watampone on 1987. She took her bachelor degree on 1993 at STKIP Muhammadiyah Bone, major in PLS, then she took her second bachelor degree in the same school on 1999 major in Indonesian Language. On 2009 she took her master degree on Indonesian Language at State University of Makassar. Then her Doctoral at the same university on 2014.

On 1992-1996 she became an administration staff at STKIP Muhammadiyah Bone. Then she became a secretary of LP2M STIKIP Muhammadiyah Bone on 1997-2005. On 2006 until now she is a Chief Administration at STIKIP Muhammadiyah Bone and also a lecturer in the same school. Researches that have been done under the tittle: The application of integrated learning and listening on student grade X MAN 2 Bone on 2013. The effectiveness of SQ3R learning method on reading skill at National Junior High School in district Bone.

Anshari was born in South Sulawesi Regency Enrekang, on 29 April 1964. His formal education was in SD Negeri 2 Maccini Ujung Pandang. He finished it in 1972. He continued her study to SMP Negeri 10 Ujung Pandang graduated in 1980, and then he continued her study to SMA Negeri 4 Ujung Pandang and finished in 1983. He achieved Masters of Humanities (M. Hum) in 1999 and his Ph.D. (Dr.) in 2007 in the Indonesian Language Education at the Graduate Program, State University of Malang. He was appointed as Professor at the State University of Makassar.

There are some scientific papers in the field of research that has produced. The first is "The Correlation between Interests and Capabilities in Appreciation of Students' Literary Works at SMAN 4 Makassar". The second is "Development of Indonesian Language at the time of the occupation of Japan: the study of Sinkronik, TMPD Foundation and Toyota Japan". The third is "humanitarian values in the Makassar Linrilik literature". The fourth is "Discourse analysis: review of the Business Publication: the use of foreign languages in Makassar". The fifth is "Gender equality in the novels at Balai Pustaka generation, research. Directorate of the Research and Community Service.

He has written some books that have ISBN The first is "Development of the Indonesia Language Vocabulary" (2001). The second is "Type of Relation of Humanitarian Values in The Jinrilik Literature" (2007). The third is "The Proceedings of the Congress, The Regional Languages of South Sulawesi" (2007). The fourth is "The Development of Indonesian Language Functions during the Occupation of Japan" (2008). The fifth is "Guidelines for Preparing the Implementation Plan of Learning Based on the Curriculum Unit Level of Education" (2010).

Mayong Maman, was born on December 31, 1963 in Bima, NTB. In 1987, he graduated from FPS IKIP Ujung Pandang (now FBS Universitas Negeri Makassar), where he received a bachelor degree in Indonesian language program. In the same year, he became a lecturer assistant. On March 1, 1988 he was appointed as a lecturer of FPBS IKIP Ujung Pandang. He took his magister degree in 1995 at PPS IKIP Malang and got his doctoral in 2011.

As an academician, he was an active participant in various national or international seminars and symposiums. He also did his research and taught in some private universities and high schools in Makassar, such as UMI, STIE YPUP, and STPP Gowa. In addition, he actively trained pre-school children and teenage or youth group of some mosques in reading poetry and communication ethic. He also became as a speaker in scientific seminars and a trainer for teachers in South Sulawesi. Moreover, he reviewed teaching material of literatures at SD Puskur Balibang Diknas RI. He became as a volunteer teacher in some primary, junior high, or senior high school. He spent as an author for editorial column in local newspaper and as an informant speaker in some shows of local television. Later, he served as a Lektor Kepala or Senior Lecturer rank IV at Universitas Negeri Makassar. 